\title{
A review of mother-child and birth cohort studies in the Middle East Area
}

\author{
Eleni Fthenou*1, Samah Aboulsoud ${ }^{2}$, Vasiliki Leventakou ${ }^{2}$, Alexandra Haddad ${ }^{2}$, Manolis Kogevinas ${ }^{3}$, Eman Sadoun ${ }^{2}$ \\ ${ }^{1}$ Qatar Biobank, Doha, Qatar \\ ${ }^{2}$ Health Research Governance Department, Ministry of Public Health Qatar, Doha, Qatar \\ ${ }^{3}$ Barcelona Institute for Global Health, Barcelona, Spain
}

Received: June 7, 2020

DOI: $10.5430 /$ jer.v6n1p22
Accepted: August 24, $2020 \quad$ Online Published: January 7, 2021

URL: https://doi.org/10.5430/jer.v6n1p22

\begin{abstract}
Mother-Child and Birth cohort studies offer an excellent opportunity to evaluate the effects of 'early life' exposures providing an insight in the etiology of chronic diseases. To our knowledge, this is the first study that aims to provide a comprehensive review of these studies in the Middle East Area (MEA). Authors searched to relevant registries, the Pubmed interface, internet search tools and had personal contact with study PIs. The search revealed 117 mother-child and birth cohort studies from 9 MEA region countries (Iran, Israel, Jordan, Kuwait, Lebanon, Palestine, Saudi Arabia, United Arab Emirates and Qatar). Variability in the identified studies refers to the study design, objectives and the years of recruitment. Biological samples and data on environmental exposures were absent with the exception of limited studies $(n=44)$. This review revealed a sufficient number of available cohorts, however few have followed up children beyond the age of 2 years. Improved study designs focused on molecular and environmental data acquisition are required in a region that shares a set of unique characteristics in terms of landscape, climate, culture, and lifestyle. This review provides valuable information for planning future studies and set the grounds for collaborations within the MEA region and internationally.
\end{abstract}

Key Words: Maternal health, Child health, Birth cohorts, Mother-child cohorts, Middle East Area

\section{INTRODUCTION}

Numerous longitudinal pregnancy, mother-child or birth cohort studies have been established in different countries to aid our understanding of child health and wellbeing and, in the longer terms, the etiology of non-communicable diseases (NCDs) in adulthood. The global burden of NCDs is rapidly growing and according to the NCDs Progress Monitor 2017 released by the World Health Organization (WHO) in 2017 NCDs are responsible for the $70 \%$ of deaths worldwide. ${ }^{[1]}$ Based on a recent report more than $30 \%$ of school children (13 to 15 years) in Bahrain, Egypt, Kuwait, Oman, and the United Arab Emirates (UAE) are either overweight or obese. ${ }^{[2]}$ The Middle East and North Africa (MENA) region has also been identified by the International Diabetes
Federation (IDF) as having the highest prevalence of diabetes in the world. According to the IDF Diabetes Atlas (8th Edition), almost 38.7 million adults (20-79 years) had diabetes in the MENA region in 2017. ${ }^{[3]}$ However, the leading cause of death not only in the Middle East Area (MEA) region but globally remains the cardiovascular diseases. It is estimated that 1.4 million of CVD deaths occurred in the Eastern Mediterranean region in 2015. ${ }^{[4]}$

Although the underline causes of this unobstructed raise of NCDs are not clear, there is substantial epidemiological evidence suggesting that an adverse intrauterine environment alongside with genetic predisposition, may program susceptibility of the fetus to later development of chronic diseases. ${ }^{[5]}$

*Correspondence: Eleni Fthenou; Email: efthenou@qf.org.qa; Address: Hamad Medical City, Building 317 PO Box: 5825 Doha, Qatar. 
The concept known today as the Developmental Origin of Health and Disease (DOHaD) was originally proposed by Dorner (first to use the term 'programming'), but received broader recognition by Barker et al. by showing the associations between maternal undernutrition, infant low birth weight and a higher risk for developing cardiovascular disease in later life. ${ }^{[6-8]}$ Over recent decades, within this model new indicators of altered fetal development have emerged which have far escaped the nutritional aspects. ${ }^{[9,10]}$ As a result, new generation epidemiological studies have been established with developmental considerations, not being restricted to fetal life but throughout the lifespan.

The study design of pregnancy and birth cohort studies are ideally suited to strengthen causal inference between early life stressors (even before birth during intrauterine development), genetic susceptibility, childhood health and the development of complex and common diseases in adulthood. The life course approach of these studies, with long-term follow ups, enables the timely identification of phenotypic profile at risk. They generate enormous and comprehensive data repositories sufficient to assess or to have the potential to assess the effect of early life stressors along with those accruing in adulthood or transmitted over generations, on health risk. ${ }^{[7,11-14]}$ Modern birth cohort studies use the recent advantages in biotechnology and exposure assessment technologies with high-throughput, sophisticated molecular platforms (abbreviated as '-omics' encompassing genomics, transcriptomics, proteomics, metabolomics, epigenomics and others) introducing molecular epidemiology and a new era of biomarkers (exposure, susceptibility and early response). More specifically, the study design of these cohorts utilize traditional epidemiological tools (i.e. questionnaires, clinical examinations, etc.) with advanced exposure assessment technologies (i.e. environmental monitoring and modern techniques such as sensors, smartphones and Geographic Information Systems (GIS)), and '-omics' platforms, to capture a wide range of exposures and their associations with disease onset. ${ }^{[15-18]}$ This is a unique monitoring approach for the processes of the disease development, tracking, at multiple levels and systems (i.e. molecular, environmental, physical, behavioral, mental, etc.), assessing how fast one degenerates from its optimum and its relevance to the occurrence of the disease. Current literature provides a large number of research papers using data from birth cohort studies, highlighting their essential contribution to understanding individual's vulnerability to disease during early stages of life.

In the last twenty years, birth and pregnancy cohort studies have gained high recognition in Europe, United States,
Canada and Australia with numerous cohorts being established in these countries. ${ }^{[13,19-21]}$ Moreover, a number of web-based networks and inventories (www.micyrn .cainCanada; www.lifecycle-project.eu/for-sci entists/the-eu-child-cohort-network,www.chic osproject.eu/cohorts and www.closer.ac.uk in Europe; ww. niehs.nih.gov/research/supported/coh ort/index.cfm in USA; www. birthcohorts.net) have been created with main objective to provide information on available cohorts and foster collaborations among them. In the MEA region, available evidence in this research field is currently underrepresented in the literature. The identification of completed, ongoing or newly planned cohorts in the MEA region will provide researchers with a valuable source of information of what is currently available and develop the capacity for an attempt to create birth-cohort networks in the Middle East. The full potential of individual cohorts can be fully revealed through these birth cohort networks which will provide a great opportunity for common analysis (data sharing), pooling data across the different studies, increase statistical power and eliminate chance findings via replication of results. ${ }^{[22-25]}$

The main aim of present study is to provide an overview of the ongoing or planned mother-child and/or birth cohort studies in the MEA region, currently missing from literature. Given the specific characteristics of the population and the great diversity in, lifestyle, socioeconomic structure and cultural practices, this review intends to offer a broader geographical representation of these studies and facilitate collaboration across the cohorts not only within the MEA region but internationally. Additionally, this review will be a source of information that needs to be considered by researchers with respect to new research hypotheses, to study methodology and to type of data planned for future studies to be collected. To our knowledge, this is the first review in the Middle East Area of the available mother-child and birth cohort studies.

\section{METHODS}

A structured review was implemented as a search strategy to identify mother-child and birth cohort studies conducted solely in MEA countries or as part of an international initiative. The geographic boundaries of the Middle East Area vary in the literature. In this review, MEA refers to the area that is enclosed by the Eastern Mediterranean and the Red Sea extended over the Arabic Peninsula, including the following countries: Bahrain, Iran, Iraq, Israel, Jordan, Lebanon, Syria, Kuwait, Oman, Palestine, Qatar, Saudi Arabia, UAE and Yemen (see Figure 1). 


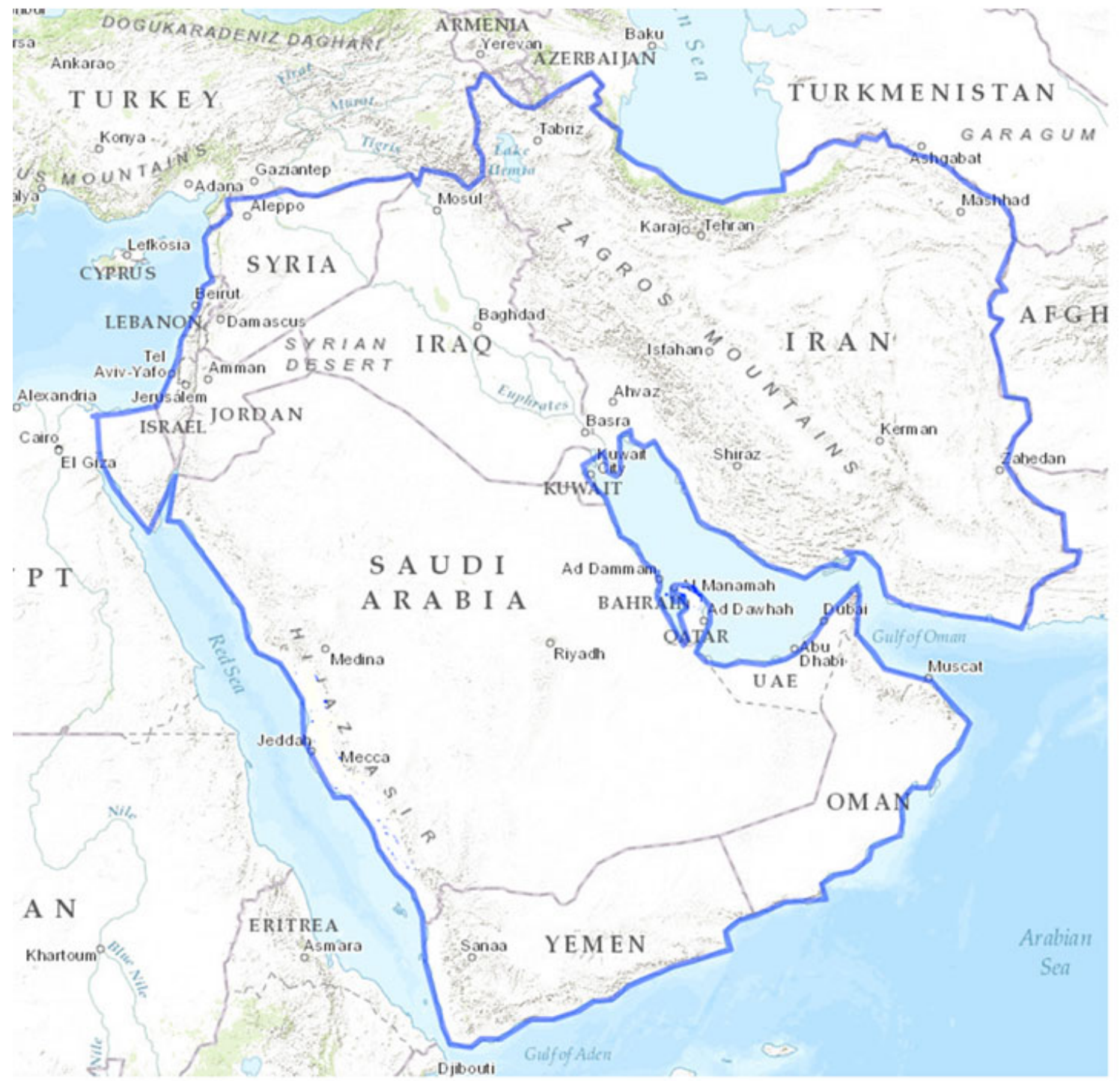

Figure 1. Geographical representation of the Middle East Area region for the current review. (To develop this map the authors used USGS National Map Viewer, http://viewer.nationalmap.gov/viewer/)

Table 1. Search Strategy for Medline: MESH Terms used to identify relevant studies

\begin{tabular}{|c|c|c|}
\hline 1. "mothers" & & 5. "longitudinal studies" \\
\hline 2. "child" & & 6. "studies" \\
\hline "parturition" & OR & 7. "prospective" \\
\hline 4. "birth" & & 8. "cohort" \\
\hline \multicolumn{3}{|c|}{ AND } \\
\hline 9. $\quad$ "Middle East" & & 17. "Kuwait" \\
\hline 10. "Bahrain & & 18. "Oman" \\
\hline 11. "Iran" & & 19. "Palestine" \\
\hline 12. "Iraq" & & 20. "Qatar" \\
\hline 13. "Israel" & & 21. "Saudi Arabia" \\
\hline 14. "Jordan" & & 22. "UAE" \\
\hline 15. "Lebanon" & & 23. "Yemen" \\
\hline 16. "Syria" & & \\
\hline
\end{tabular}

\subsection{Identification of MEA Mother-Child and Birth co- hort studies}

MEA mother-child and birth cohort studies were identified from multiple sources. We first searched the web-based database LINK Registry (http://www.linkregistry.o $\mathrm{rg} /$ search . aspx; link currently not available) for the timeperiod starting October to December 2015. The LINK Registry was a database of pregnancy and birth cohort studies from around the world, designed to promote collaboration among researchers by sharing information on participant population, biospecimens and data collected in different studies and information about planned studies. Additionally, we searched (October 2015 to October 2019) the web-based database http://birthcohorts.net. This database is an open registration of cohorts worldwide, which collect 
information on specific exposures, outcomes or biological samples of interest. One additional study was identified by searches of Google and Google Scholar (October 2015 to October 2019).

\subsection{Literature search strategy}

Published peer reviewed papers were identified using Medline (National Library of Medicine) dataset. The literature search was initiated on 17th of October 2015 and completed on 8th of October 2019 using the PubMed interface. Search terms used were chosen from the USNLM Institute of Health list of Medical Subject Headings (MESH) for 2017 as follows: Mother, Child, Birth, Prospective, Cohort, Middle East, Bahrain, Iran, Iraq, Israel, Jordan, Lebanon, Syria, Kuwait, Oman, Palestine, Qatar, Saudi Arabia, UAE and Yemen. Full details of the research strategy and key terms' combination are provided in Table 1. The authors have chosen a study coding to facilitate the report and discussion of results.
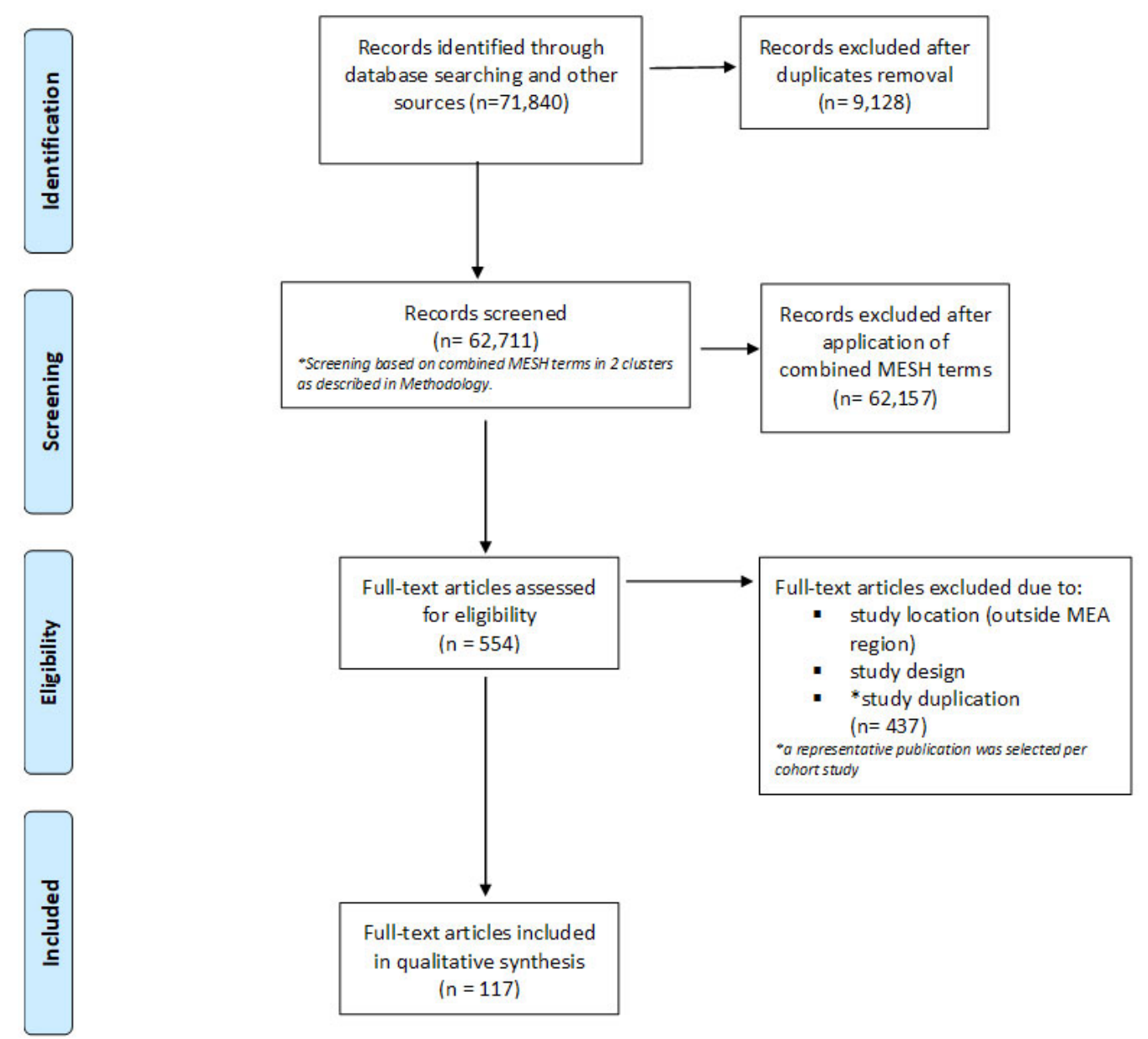

Figure 2. PRISMA flow diagram of the MEA cohort studies selection process

Table 2. Brief description of the different cohort study categorization included in the current review

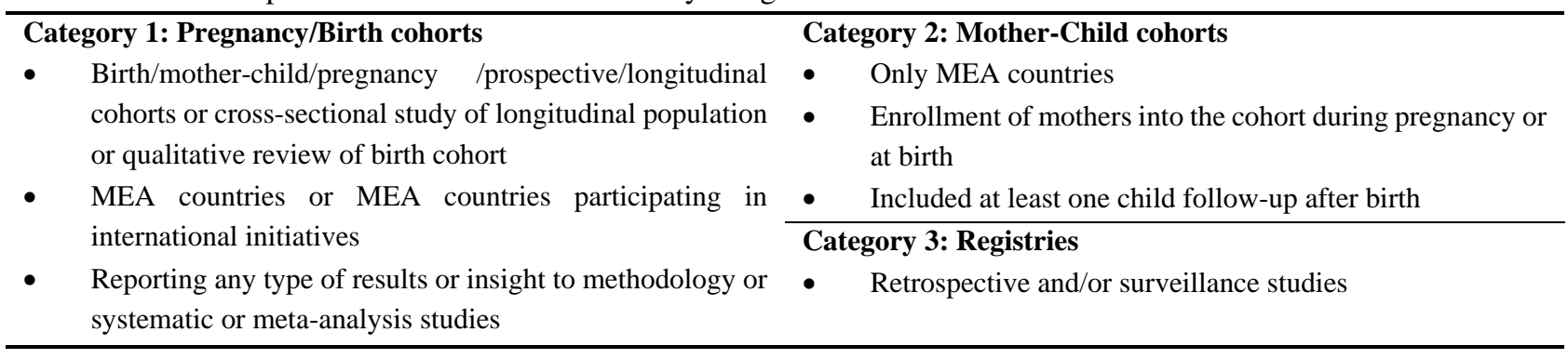


The initial search was done using each of the MESH terms alternatively with each MEA country. Studies were included based on the following: cohort design, study location and follow up status. The publications were saved initially under the country's name in a separate library and the duplicates were removed. As shown in Figure 2, all the publications of each country were compiled together $(n=71,840)$, duplicates were cleared $(n=9,128)$ and a total of 62,711 publications were included in the general MEA library. Filtering this library by using the following combined MESH terms: mother, child, birth, Middle East, prospective, cohort, resulted in 554 papers excluding the duplicates. Titles, abstracts and full text of the studies were revised by two independent reviewers for relevance. Disagreement between the reviewers was solved either by consensus or by including a third reviewer. At this point, 437 papers were excluded resulting to 117 publications (authors have selected a representative publication for each cohort study).

Then studies were divided into three main categories based on the criteria-, described in Table 2. A total of 117 cohort studies were identified of which 42 fall under Category 1 that refers to Pregnancy/Birth cohorts (following women during their pregnancy up to delivery/birth) and 75 under Category 2 for Mother-Child cohorts (following mother-child pairs; women during their pregnancy, at delivery and their child/children after birth). Additionally, from this search 7 Registries (Category 3) were identified supporting motherchild and/or birth cohort studies' research. Information extracted from publications included recruitment period, study population, time points of follow up, data collection and biological samples collected.

\section{Results}

In total, 42 mother-child cohorts were included through the current literature review. These studies have been conducted solely in MEA countries or as part of an international initiative and included at least one child follow up after birth (see Supplement 1). Most of the studies were identified in Iran (n = 16) following Israel $(n=12)$, Kingdom of Saudi Arabia ( $n$ $=5)$, Kuwait $(\mathrm{n}=2)$, United Arab Emirates $(\mathrm{n}=3)$, Jordan ( $=2)$, Qatar $(n=1)$ and a collaboration study between Qatar and Lebanon $(n=1)$. As it is shown in Supplement 1, the number of the mother-child participants varies from 50 (IR1, Iran) to 750,000 (IL33, Israel), the duration of the studies ranged from few months to multiple years (IL27, duration: 1991-2014) and the objectives of the studies mainly included birth outcomes, pregnancy and neonatal complications, maternal mental health, child development, nutrition and infant feeding practices. The majority of the studies did not have available maternal or child biological samples with the exception of IR8, 10, 35, 49; IL1, 2, 7, 31, 33; J1; KW2; KS1, 2, 3 4, 9; QA1 and Qatar/ Lebanon collaboration cohort.

Supplement 2 includes 75 pregnancy or birth cohorts as identified from publications review and via web-based registries. In this group, Iran and Israel counted the majority of these studies with 34 and 18 cohorts, respectively; followed by Kingdom of Saudi Arabia with $(n=5)$, Palestine $(n=4)$, Jordan $(n=2)$, Oman $(n=2)$, Kuwait $(n=2)$, Yemen $(n=$ 2), Qatar ( $\mathrm{n}=2)$ and Lebanon, Syria and United Arab Emirates and a collaborative study (between Kuwait, KSA and UAE) with one cohort each. As it is shown in Table 4, the number of the participants varies from 44 (IR28, Iran) to 201,048 (IL29). The duration of the studies ranges from less than a year to decades (IL29) and the objectives of these studies were mainly mortality, birth outcomes, pregnancy complications, environmental exposures and maternal health. $\mathrm{OM} 2$, a study from Oman was a part of Intergrowth $21 \mathrm{st}$ Project, an international initiative. In 29 studies, Iran ( $\mathrm{n}=$ 16), Israel ( $n=3)$, Jordan ( $n=1)$, Oman ( $n=2)$, Kingdom of Saudi Arabia ( $n=3)$, United Arab Emirates $(n=1)$, Qatar $(\mathrm{n}=1)$, Yemen $(\mathrm{n}=1)$ and in a collaboration study $(\mathrm{n}=1)$ were used biological samples.

As shown in Supplements 1 and 2, a total of 16 cohorts have followed women during their pregnancy (Iran, $\mathrm{n}=19$; Israel, $\mathrm{n}=5$; Kingdom of Saudi Arabia, $\mathrm{n}=5$; Palestine, $\mathrm{n}=1$; Kuwait, $n=1$ and Qatar, $n=3$ ). Two of these cohorts (QA1 \& Qatar/Lebanon collaboration cohort) are ongoing and currently collecting data on pregnant women. Studies with available information for mothers after delivery focusing on postpartum depression or other stress symptoms (antenatal anxiety, post-traumatic stress, maternal/fetal attachment) during or after pregnancy have been identified in Iran (IR37, 46, 2, 13, 32), Israel (IL4, 10, 12, 14, 26), Palestine (PS2) and Qatar (QA1). MEA Birth registry initiatives have also been covered by this review. Table 3 presents 7 birth registries as identified from the analysis of both manuscripts reviews and the web-based registires. In Israel there are found four registries IL22-25. IL22 is an ongoing registry collecting data on maternal exposure to chemicals and the birth abnormalities based on the Teratogenic Information Service, while the other three registries include longterm follow ups, up of 12 years. In Lebanon, LB2 registry collected data on neonatal mortality for a year for a popualtion of 5,152 and in Qatar, QA2, collected data on perinatal mortality for a year to a total of 20,583 population. 
Table 3. Description of Birth Registries in the MEA region

\begin{tabular}{|c|c|c|c|c|c|c|c|c|c|c|}
\hline Country & $\begin{array}{l}\text { Study } \\
\text { Coding }\end{array}$ & Source & $\begin{array}{l}\text { Duration } \\
\text { of the } \\
\text { study }\end{array}$ & Population & $\begin{array}{l}\text { Pre- } \\
\text { natal }\end{array}$ & $\begin{array}{l}\text { Post- } \\
\text { natal }\end{array}$ & Objectives & $\begin{array}{l}\text { Data } \\
\text { Collection }\end{array}$ & $\begin{array}{l}\text { Biological } \\
\text { samples }\end{array}$ & $\begin{array}{l}\text { Follow } \\
\text { Up }\end{array}$ \\
\hline \multirow[t]{4}{*}{ Israel } & IL22 & $\begin{array}{l}(26,27) \\
(28-32) \\
(33)\end{array}$ & $\begin{array}{l}\text { 1985- } \\
\text { present }\end{array}$ & $\begin{array}{l}\text { Teratology } \\
\text { Information } \\
\text { Service }\end{array}$ & $\checkmark$ & $\checkmark$ & $\begin{array}{l}\text { Maternal } \\
\text { exposure/major } \\
\text { anomalies }\end{array}$ & $\begin{array}{l}\text { Q: maternal } \\
\text { demographics, } \\
\text { medical and } \\
\text { obstetric } \\
\text { histories, } \\
\text { exposure } \\
\text { details (dose, } \\
\text { duration, route } \\
\text { of } \\
\text { administration, } \\
\text { timing in } \\
\text { pregnancy and } \\
\text { indication for } \\
\text { therapy), } \\
\text { concurrent } \\
\text { exposures, BO }\end{array}$ & NA & NA \\
\hline & IL23 & (34) & 1964-1976 & 92408 & - & $\checkmark$ & Registry & $\mathrm{Q}$ & - & 17 years \\
\hline & IL24 & (35) & 1995-2012 & 3956 & - & $\checkmark$ & $\begin{array}{l}\text { VLBW } \\
\text { Neonatal } \\
\text { morbidities }\end{array}$ & Medical records & NA & 11 years \\
\hline & IL25 & (36) & 1997-2004 & 220805 & - & $\checkmark$ & Risk for cancer & $\begin{array}{l}\text { Israel National } \\
\text { Cancer registry }\end{array}$ & NA & 10 years \\
\hline Lebanon & LB2 & (37) & $2002-2003$ & 5152 & - & $\checkmark$ & $\begin{array}{l}\text { Neonatal } \\
\text { mortality }\end{array}$ & Medical records & - & Birth \\
\hline Palestine & PS4 & (38) & 2015 & 34482 & - & - & $\begin{array}{l}\text { Built a research } \\
\text { registry }\end{array}$ & Medical records & - & NA \\
\hline Qatar & QA2 & (39) & 2011 & 20583 & - & $\checkmark$ & $\begin{array}{l}\text { Perinatal } \\
\text { mortality }\end{array}$ & $\begin{array}{l}\text { Medical } \\
\text { Records }\end{array}$ & - & Birth \\
\hline
\end{tabular}

\section{Discussion}

This review provides an insight of the notable efforts from the MEA local institutions and/or research teams to set up longitudinal mother-child and birth cohort studies. The identified studies show a great variability on the study design, the follow up of their population, as well as the data and specimen collection. Some of the studies are general pregnancy cohorts with various aims, while others focus on evaluating specific outcomes (i.e. breastfeeding or nutrition) and others are simple registries. Despite the substantial efforts made in the MEA to initiate birth cohorts, these efforts lack of frequent and long term follow up points after birth, with limited biological samples collection. Given the emergence of advanced technologies and sophisticated genetic analyses, the assessment of biological and environmental factors needs to be further acknowledged. Longitudinal birth cohort studies are essential to understanding the life course, risk, early predictors and protective factor for the development of chronic diseases, as well as the complex interplay between genes and environment. According to the current literature, the majority of the published papers about the DO$\mathrm{HaD}$ concept mainly comes from birth cohort studies from the West, while as it is shown in this review, the published papers coming from MEA cohorts are limited. This could be attributed to the relative wealth of Western societies and their ability to provide appropriate infrastructure and long-term funding to support these longitudinal birth cohort studies. The role of national and international funding organizations appears to be critical for the initiation and, most important, the maintenance of such studies. ${ }^{[40]}$ The establishment of long-term birth cohort studies requires a huge investment in time, effort and money. In West, mainly In Europe, for the past two decades, longitudinal studies have been supported by different organizations providing funding schemes suitable for supporting such studies. The economic deficits in some MEA countries could impede funding opportunities for scientific research projects and especially for longitudinal studies where long-term funding is essential.

The importance of national registries or even big data repositories for the surveillance of diseases and population characteristics should also be acknowledged. Well-maintained registries with accumulating data are mainly used to provide information for rare diseases (e.g. cystic fibrosis), evaluate survival predictors and changes in survival, and monitor the 
health of the population. However, there is no doubt that the use of registry data need to overcome several challenges such as privacy protection, completeness of patient records, data quality, variable definitions, reference ranges that may vary by country, and data harmonization. Despite the challenges that may encounter, the liaison between birth cohorts and registries is a great opportunity for research especially when focusing on specific health or exposure-related questions. As shown previously, in the MEA region only few registries are currently available with no information for collaborations between cohorts and registries. However, in the recent and following years researchers and policy makers should make better efforts to make sustainable registries that will be able to work more with other parts of the health system. Advances in current research require scientists from a wide range of expertise who will be able to address questions, and use available data, that individual cohorts may not have thought of. The development of new or existing cohorts in combination with other study designs (case-control, clinical trial) and registries is desirable. Well-designed electronic platforms for data collection, automated derivation of required variables, data quality checks and positive attitudes by researchers towards data sharing are some of the actions that will support this endeavor. Although in West (Europe and the US), cohorts are trying to build a network by harmonizing their protocols and pool their data together, it is important to mention that there is no provision for MEA regional and/or global partnerships. Collaborative efforts in Europe such as the ENRIECO (www.enrieco.org), CHICOS (chicosproject.eu) and HELIX (www. projecthelix.eu) projects are important lessons that could help MEA region countries develop this field further. There is clear need for collaboration between the cohorts or the harmonization of new data and biological sample collection that will allow the study of long term outcomes and prevent the overlap of measures among the studies.

Cohort studies are expensive and time-consuming type of studies. Researchers have to address many challenges such as recruitment, retention rates, fund resources and manage logistics, especially in large scale cohorts with long term follow ups. Based on this review, authors observed that many of the studies in the Middle East lack of frequent, long term or had no follow up points after birth and missed collection of biological samples. Due to the study design and/or the absence of long term follow ups, current studies are not able to provide evidence on the etiology of main health concerns in the region such as diabetes, obesity, cardiovascular diseases. While the setup of a new cohort would be ideal, the design of new follow-ups, including collection of biological samples of the already existing cohorts with harmonized protocols focused of the main burden of diseases in MEA region would much more benefit research. More efficient methods, innovative technologies (smartphones, apps, email, social media) along with the experience of researchers in this specific geographical area can be in favor of research by simplifying logistics and minimizing the cost of current studies. New birth cohorts or the existing ones can only provide novel insight into early predictors of the disease onset through collaborations if researchers are able to promptly respond and shift research in line with scientific changes and infrastructural needs.

\section{AUTHORS' CONTRIBUTION}

E.F contributed to the conception and design of the work; literature review, analysis and interpretation of the data, manuscript writing; S.A contributed to literature review, analysis and interpretation of the data, manuscript writing; V.L contributed to literature review, analysis and interpretation of the data, manuscript writing; A.H contributed to literature review, analysis and interpretation of the data; M.K contributed to the ensuring that questions related to the accuracy or integrity of any part of the work are appropriately investigated and resolved; E.S contributed to the accuracy or integrity of any part of the work are appropriately investigated and resolved and the final approval of the version to be published.

\section{ACKNOWLEDGEMENTS}

The authors developed the map presented in this article (Figure 1) with the use of the United States Geological Survey (USGS), The National Map Viewer, http://viewer.nationalmap.gov/viewer/.

\section{CONFlicts OF INTEREST Disclosure}

The authors declare that they have no competing interests.

\section{REFERENCES}

[1] World Health Organization (WHO). Non communicable Diseases Progress Monitor 2017. 2017: Geneva.

[2] Bureau PR. NONCOMMUNICABLE DISEASES IN THE MIDDLE EAST AND NORTH AFRICA: Addressing Risk Factors Among Young People Is Key to Curbing the Epidemic. Data Sheet. 2017.
[3] International Diabetes Federation Date. 2017.

[4] Collaborators GBDEMRCD. Burden of cardiovascular diseases in the Eastern Mediterranean Region, 1990-2015: findings from the Global Burden of Disease 2015 study. International journal of public health. 2018; 63(Suppl 1): 137-49. PMid:28776245. https: //doi.org/10.1007/s00038-017-1012-3 
[5] Gluckman PD, Hanson MA, Cooper C, et al. Effect of in utero and early-life conditions on adult health and disease. The New England journal of medicine. 2008; 359(1): 61-73. PMid:18596274. https://doi.org/10.1056/NEJMra0708473

[6] Barker DJ. In utero programming of chronic disease. Clin Sci (Lond). 1998; 95(2): 115-28. https://doi.org/10.1042/cs0950115

[7] Barker DJ, Winter PD, Osmond C, et al. Weight in infancy and death from ischaemic heart disease. Lancet. 1989; 2(8663): 577-80. https://doi.org/10.1016/S0140-6736 (89) 90710-1

[8] Koletzko B. Developmental origins of adult disease: Barker's or Dorner's hypothesis? American journal of human biology: the official journal of the Human Biology Council. 2005; 17(3): 381-2. PMid:15849708. https://doi.org/10.1002/ajhb. 20139

[9] Bale TL, Baram TZ, Brown AS, et al. Early life programming and neurodevelopmental disorders. Biological psychiatry. 2010; 68(4): 314-9. PMid:20674602. https://doi.org/10.1016/j.biopsy ch.2010.05.028

[10] Gluckman PD, Hanson MA, Buklijas T. A conceptual framework for the developmental origins of health and disease. Journal of Developmental Origins of Health and Disease. 2010; 1(1): 6-18. PMid:25142928. https://doi.org/10.1017/S2040174409990 171

[11] Barker DJ, Osmond C, Golding J, et al. Growth in utero, blood pressure in childhood and adult life, and mortality from cardiovascular disease. BMJ. 1989; 298(6673): 564-7. PMid:2495113. https://doi.org/10.1136/bmj.298.6673.564

[12] Kuh D, Ben-Shlomo Y, Lynch J, et al. Life course epidemiology. Journal of epidemiology and community health. 2003; 57(10): 778-83. PMid:14573579. https://doi.org/10.1136/jech.57.10.778

[13] Larsen PS, Kamper-Jorgensen M, Adamson A, et al. Pregnancy and birth cohort resources in europe: a large opportunity for aetiological child health research. Paediatric and Perinatal Epidemiology. 2013; 27(4): 393-414. PMid:23772942. https ://doi .org/10.1111/pp e. 12060

[14] Lynch J, Smith GD. A life course approach to chronic disease epidemiology. Annual review of public health. 2005; 26: 1-35. PMid:15760279. https://doi.org/10.1146/annurev.publhe alth.26.021304.144505

[15] Hasin Y, Seldin M, Lusis A. Multi-omics approaches to disease. Genome Biology. 2017; 18(1): 83. PMid:28476144. https://doi . org/10.1186/s13059-017-1215-1

[16] Vrijheid M. The exposome: a new paradigm to study the impact of environment on health. Thorax. 2014; 69(9): 876-8. PMid:24906490. https://doi.org/10.1136/thoraxjnl-2013-204949

[17] Vrijheid M, Casas M, Bergstrom A, et al. European birth cohorts for environmental health research. Environmental Health Perspectives. 2012; 120(1): 29-37. PMid:21878421. https://doi.org/10.128 9/ehp. 1103823

[18] Yan J, Risacher SL, Shen L, et al. Network approaches to systems biology analysis of complex disease: integrative methods for multiomics data. Brief Bioinform. 2017. https://doi.org/10.1093/ bib/bbx066

[19] Felix JF, Joubert BR, Baccarelli AA, et al. Cohort Profile: Pregnancy And Childhood Epigenetics (PACE) Consortium. International Journal of Epidemiology. 2018; 47(1): 22-3u. PMid:29040532. https://doi.org/10.1093/ije/dyx220

[20] Joly MP, Boivin M, Junker A, et al. An inventory of Canadian pregnancy and birth cohort studies: research in progress. BMC Pregnancy and Childbirth. 2012; 12: 117. PMid:23101595. https: //doi.org/10.1186/1471-2393-12-117

[21] Townsend ML, Riepsamen A, Georgiou C, et al. Longitudinal Intergenerational Birth Cohort Designs: A Systematic Review of Aus- tralian and New Zealand Studies. PloS one. 2016; 11(3): e0150491. PMid:26991330. https://doi.org/10.1371/journal.pone.0 150491

[22] Bousquet J, Anto J, Sunyer J, et al. Pooling birth cohorts in allergy and asthma: European Union-funded initiatives - a MeDALL, CHICOS, ENRIECO, and GA(2)LEN joint paper. International Archives of Allergy and Immunology. 2013; 161(1): 1-10. PMid:23258290. https://doi.org/10.1159/000343018

[23] Gehring U, Casas M, Brunekreef B, et al. Environmental exposure assessment in European birth cohorts: results from the ENRIECO project. Environmental health : a global access science source. 2013; 12: 8. PMid:23343014. https://doi.org/10.1186/1476-069 $\mathrm{X}-12-8$

[24] Kogevinas M, Andersen AM, Olsen J. Collaboration is needed to co-ordinate European birth cohort studies. International Journal of Epidemiology. 2004; 33(6): 1172-3. PMid:15333624. https : //doi.org/10.1093/ije/dyh318

[25] Vrijheid M, Slama R, Robinson O, et al. The human early-life exposome (HELIX): project rationale and design. Environmental Health Perspectives. 2014; 122(6): 535-44. PMid:24610234. https://doi.org/10.1289/ehp.1307204

[26] Berkovitch M, Diav-Citrin O, Greenberg R, et al. First-trimester exposure to amoxycillin/clavulanic acid: a prospective, controlled study. British journal of clinical pharmacology. 2004; 58(3): 298-302. PMid:15327589. https://doi.org/10.1111/j.1365-2125.20 04.02138. $\mathrm{x}$

[27] Berkovitch M, Segal-Socher I, Greenberg R, et al. First trimester exposure to cefuroxime: a prospective cohort study. British Journal of Clinical Pharmacology. 2000; 50(2): 161-5. PMid:10930968. https://doi.org/10.1046/j.1365-2125.2000.00240.x

[28] Diav-Citrin O, Shechtman S, Arnon J, Lubart I, Ornoy A. Pregnancy outcome after gestational exposure to mebendazole: a prospective controlled cohort study. American Journal of Obstetrics and Gynecology. 2003; 188(1): 282-5. PMid:12548230. https ://doi.org/ 10.1067/mob. 2003.79

[29] Diav-Citrin O, Shechtman S, Gotteiner T, et al. Pregnancy outcome after gestational exposure to metronidazole: a prospective controlled cohort study. Teratology. 2001; 63(5): 186-92. PMid:11320529. https://doi.org/10.1002/tera.1033

[30] Diav-Citrin O, Shechtman S, Halberstadt Y, et al. Pregnancy outcome after in utero exposure to angiotensin converting enzyme inhibitors or angiotensin receptor blockers. Reproductive Toxicology. 2011; 31(4): 540-5. PMid:21338666. https ://doi .org/10.1016/j.reprot ox.2011.02.008

[31] Diav-Citrin O, Shechtman S, Schwartz V, et al. Pregnancy outcome after in utero exposure to colchicine. American Journal of Obstetrics and Gynecology. 2010; 203(2): 144 e1-6. PMid:20579964. https://doi.org/10.1016/j.ajog.2010.02.063

[32] Gur C, Diav-Citrin O, Shechtman S, et al. Pregnancy outcome after first trimester exposure to corticosteroids: a prospective controlled study. Reproductive Toxicology. 2004; 18(1): 93-101. PMid:15013068. https://doi.org/10.1016/j.reprotox.200 3.10 .007

[33] Rosenfeld H, Ornoy A, Shechtman S, et al. Pregnancy outcome, thyroid dysfunction and fetal goitre after in utero exposure to propylthiouracil: a controlled cohort study. British Journal of Clinical Pharmacology. 2009; 68(4): 609-17. PMid:19843064. https: //doi.org/10.1111/j.1365-2125.2009.03495.x

[34] Harlap S, Davies AM, Deutsch L, et al. The Jerusalem Perinatal Study cohort, 1964-2005: methods and a review of the main results. Paediatric and Perinatal Epidemiology. 2007; 21(3): 256-73. 
PMid:17439536. https://doi.org/10.1111/j.1365-3016.20 $07.00799 . \mathrm{x}$

[35] Kuint J, Lerner-Geva L, Chodick G, et al. Rehospitalization Through Childhood and Adolescence: Association with Neonatal Morbidities in Infants of Very Low Birth Weight. The Journal of Pediatrics. 2017; 188: 135-41 e2. PMid:28662947. https://doi .org/10.1016/j . jpeds. 2017.05 .078

[36] Lerner-Geva L, Boyko V, Ehrlich S, et al. Possible risk for cancer among children born following assisted reproductive technology in Israel. Pediatric Blood \& Cancer. 2017; 64(4). PMid:27748017. https://doi.org/10.1002/pbc. 26292

[37] Badr LK, Abdallah B, Balian S, et al. The chasm in neonatal outcomes in relation to time of birth in Lebanon. Neonatal Network: NN. 2007; 26(2): 97-102. PMid:17402601. https ://doi .org/10 $.1891 / 0730-0832.26 .2 .97$

[38] Hassan S, Vikanes A, Laine K, et al. Building a research registry for studying birth complications and outcomes in six Palestinian governmental hospitals. BMC Pregnancy and Childbirth. 2017; 17(1): 112. PMid:28399841. https://doi.org/10.1186/s12884-017 $-1296-6$

[39] Rahman S, Al RH, El AW, et al. A PEARL Study Analysis of National Neonatal, Early Neonatal, Late Neonatal, and Corrected Neonatal Mortality Rates in the State of Qatar during 2011: A Comparison with World Health Statistics 2011 and Qatar's Historic Data over a Period of 36 Years (1975-2011). Journal of Clinical Neonatology. 2012; 1(4): 195-201. PMid:24027726. https : //doi.org/10.4103/2249-4847.105990

[40] Doyle A, Golding J. The costing and funding of longitudinal birth cohort studies. Paediatric and Perinatal Epidemiology. 2009; 23 Suppl 1: 86-92. PMid:19490448. https://doi.org/10.1111/j.1365 $-3016.2008 .01011 . \mathrm{x}$

[41] Islami Z, Fallah R, Mosavian T, et al. Growth parameters of NICU admitted low birth weight preterm neonates at corrected ages of 6 and 12 month. Iranian Journal of Reproductive Medicine. 2012; 10(5): 459-64.

[42] Talachian E, Bidari A, Rezaie MH. Incidence and risk factors for infantile colic in Iranian infants. World journal of gastroenterology: WJG. 2008; 14(29): 4662-6. PMid:18698680. https : //doi.org/10.3748/wjg.14.4662

[43] Vazirinejad R, Masoodpour N, Puyanfar A. Survival rate of low and very low birth weight neonates in an Iranian community. Iranian Journal of Public Health. 2012; 41(2): 87-93.

[44] Saki N, Bayat A, Hoseinabadi R, et al. Universal newborn hearing screening in southwestern Iran. International Journal of Pediatric Otorhinolaryngology. 2017;97:89-92. https://doi.org/10.5713/ajas.2012.12023 PMid:25049697 PMCid:PMC4092948

[45] Afjeh SA, Sabzehei MK, Khoshnood Shariati M, Shamshiri AR, Esmaili F. Evaluation of Initial Respiratory Support Strategies in VLBW Neonates with RDS. Archives of Iranian Medicine. 2017; 20(3): 158-64.

[46] Ebrahimiadib N, Roohipour R, Karkhaneh R, et al. Internet-based versus Conventional Referral System for Retinopathy of Prematurity Screening in Iran. Ophthalmic Epidemiology. 2016; 23(5): 292-7. PMid:27267654. https://doi.org/10.3109/09286586.2015. 1136653

[47] Boskabadi H, Maamouri G, Tavakkol Afshari J, et al. Combination of Serum Interleukin-1beta and 6 Levels in the Diagnosis of Perinatal Asphyxia. Archives of Iranian medicine. 2016; 19(5): 312-6.

[48] Roohipoor R, Karkhaneh R, Farahani A, et al. Retinopathy of prematurity screening criteria in Iran: new screening guidelines. Archives of Disease in Childhood Fetal and Neonatal Edition. 2016; 101(4):
F288-93. PMid:27073259. https : //doi .org/10.1136/archdi schild-2015-309137

[49] Lotfi A, Shiasi K, Amini R, et al. Comparing the Effects of Two Feeding Methods on Metabolic Bone Disease in Newborns with Very Low Birth Weights. Global Journal of Health Science. 2015; 8(1): 249-54. PMid:26234967. https://doi.org/10.5539/gjhs.v8n1p249

[50] Ayatollahi SM, Sharafi Z, Haem E. Child Weight Growth Chart and Its Associated Factors in Birth Cohort of Maku Using a Growth Curve Model and LMS Method. Global Journal of Health Science. 2015; 7(6): 181-6. PMid:26153171. https ://doi.org/10.5539/ gjhs.v7n6p181

[51] Nouhjah S, Shahbazian H, Latifi SM, et al. Body mass index growth trajectories from birth through 24 months in Iranian infants of mothers with gestational diabetes mellitus. Diabetes \& Metabolic Syndrome. 2019; 13(1): 408-12. PMid:30641734. https ://doi .org/ $10.1016 / j . d s x .2018 .10 .002$

[52] Atashi V, Kohan S, Salehi Z, et al. Maternal-fetal emotional relationship during pregnancy, its related factors and outcomes in Iranian pregnant women: a panel study protocol. Reproductive Health. 2018; 15(1): 176. PMid:30333017. https://doi.org/10.1186/s129 78-018-0620-6

[53] Ghaemmaghami P, Ayatollahi SMT, Alinejad V, et al. Growth curves and their associated weight and height factors in children from birth to 4 years old in West Azerbaijan Province, northwest Iran. Archives de pediatrie : organe officiel de la Societe francaise de pediatrie. 2018; 25(6): 389-93. PMid:30119913. https://doi.org/10.101 6/j.arcped.2018.06.010

[54] Salehi-Pourmehr H, Mohammad-Alizadeh S, Jafarilar-Agdam N, et al. The association between pre-pregnancy obesity and screening results of depression for all trimesters of pregnancy, postpartum and 1 year after birth: a cohort study. Journal of Perinatal Medicine. 2018; 46(1): 87-95. PMid:28212108. https://doi.org/10.1515/jp $\mathrm{m}-2016-0277$

[55] Maharlouei N AS, Lankarani K. A Study Protocol to Follow a Birth Cohort: Fars Birth Cohort. Shiraz E-Med J. 2018; 20(3): e84308. https://doi.org/10.5812/semj.84308

[56] Holakouie-Naieni K, Nematollahi S, Mansournia MA, et al. A Population-based Prospective Study to Identify Contributors to Mother and Child Health in Suburban Communities: The Cohort Profile. Iranian Journal of Public Health. 2018; 47(3): 441-8.

[57] Bassan H, Stolar O, Geva R, et al. Intrauterine growth-restricted neonates born at term or preterm: how different? Pediatric Neurology. 2011; 44(2): 122-30. PMid:21215912. https ://doi .org/10 $.1016 /$ j.pediatrneurol. 2010.09.012

[58] Fraser D, Dagan R, Naggan L, et al. Natural history of Giardia lamblia and Cryptosporidium infections in a cohort of Israeli Bedouin infants: a study of a population in transition. The American Journal of Tropical Medicine and Hygiene. 1997; 57(5): 544-9. PMid:9392593. https://doi.org/10.4269/ajtmh.1997.57.544

[59] Katz Y, Goldberg MR, Rajuan N, et al. The prevalence and natural course of food protein-induced enterocolitis syndrome to cow's milk: a large-scale, prospective population-based study. The Journal of Allergy and Clinical Immunology. 2011; 127(3): 647-53 e1-3. PMid:21377033. https://doi.org/10.1016/j.jaci.2010.12 .1105

[60] Farhi A, Reichman B, Boyko V, et al. Maternal and neonatal health outcomes following assisted reproduction. Reproductive Biomedicine Online. 2013; 26(5): 454-61. PMid:23518031. https ://doi .org/ 10.1016/j.rbmo.2013.01.014

[61] Paz LD, Sheiner E, Wainstock T, et al. Evidence that children born at early term (37-38 6/7 weeks) are at increased risk for diabetes and obesity-related disorders. American Journal of Obstet- 
rics and Gynecology. 2017; 217(5): 588 e1-e11. PMid:28729012. https://doi.org/10.1016/j.ajog.2017.07.015

[62] Bilavsky E, Shahar-Nissan K, Pardo J, et al. Hearing outcome of infants with congenital cytomegalovirus and hearing impairment. Archives of Disease in Childhood. 2016; 101(5): 433-8. PMid:26826174. https://doi.org/10.1136/archdischild-2 015-309154

[63] Kessel I, Leib M, Levy A, et al. Does Haptoglobin Phenotype Influence Postnatal Morbidity in Preterm Neonates? American Journal of Perinatology. 2016; 33(2): 130-5. PMid:26344008. https: //doi.org/10.1055/s-0035-1560042

[64] Ben-Shmuel A, Sheiner E, Wainstock T, et al. The association between gender and pediatric respiratory morbidity. Pediatric Pulmonology. 2018; 53(9): 1225-30. PMid:29943901. https://do i.org/10.1002/ppul. 24083

[65] Preis H, Eisner M, Chen R, et al. First-time mothers' birth beliefs, preferences, and actual birth: A longitudinal observational study. Women and birth: journal of the Australian College of Midwives. 2019; 32(1): e110-e7. PMid:29753684. https://doi.org/10.1 016/j. wombi.2018.04.019

[66] Mor Z, Amit Aharon A, Sheffer R, et al. Growth, developmental achievements and vaccines timeliness of undocumented migrant children from Eritrea compared with Israelis. PloS one. 2018; 13(3): e0193219. PMid:29518105. https://doi.org/10.1371/journa 1.pone. 0193219

[67] Golan R, Kloog I, Almog R, et al. Environmental exposures and fetal growth: the Haifa pregnancy cohort study. BMC Public Health. 2018; 18(1): 132. PMid:29329571. https://doi.org/10.1186/s128 89-018-5030-8

[68] Beharier O, Sheiner E, Sergienko R, et al. Isolated single umbilical artery poses neonates at increased risk of long-term respiratory morbidity. Archives of Gynecology and Obstetrics. 2017; 296(6): 1103-7. PMid:28975407. https://doi .org/10.1007/s00404-0 $17-4541-3$

[69] Khuri-Bulos N, Lang RD, Blevins M, et al. Vitamin D deficiency among newborns in Amman, Jordan. Global Journal of Health Science. 2013; 6(1): 162-71. PMid:24373276. https ://doi .org/10 $.5539 /$ gjhs.v6n1p162

[70] Almalik MM. Understanding maternal postpartum needs: A descriptive survey of current maternal health services. Journal of Clinical Nursing. 2017; 26(23-24): 4654-63. PMid:28329433. https: //doi.org/10.1111/jocn. 13812

[71] el Mouzan MI, al Awamy BH, Absood G. Infections and sickle cell disease in Eastern Saudi Arabian children. American Journal of Diseases of Children. 1989; 143(2): 205-7. PMid:2916493. https: //doi.org/10.1001/archpedi.1989.02150140099028

[72] Wahabi H, Fayed A, Esmaeil S, et al. Prevalence and Complications of Pregestational and Gestational Diabetes in Saudi Women: Analysis from Riyadh Mother and Baby Cohort Study (RAHMA). BioMed research international. 2017; 2017: 6878263. PMid:28386562. https: //doi.org/10.1155/2017/6878263

[73] Alfadhli EM, Osman EN, Basri TH, et al. Gestational diabetes among Saudi women: prevalence, risk factors and pregnancy outcomes. Annals of Saudi Medicine. 2015; 35(3): 222-30. PMid:26409797. https://doi.org/10.5144/0256-4947.2015.222

[74] Majeed-Saidan MA, Ammari AN, AlHashem AM, et al. Effect of consanguinity on birth defects in Saudi women: results from a nested case-control study. Birth defects research Part A, Clinical and molecular teratology. 2015; 103(2): 100-4. PMid:25363692. https://doi.org/10.1002/bdra.23331

[75] Shalaby MA, Sawan ZA, Nawawi E, et al. Incidence, risk factors, and outcome of neonatal acute kidney injury: a prospective cohort study. Pediatric Nephrology. 2018; 33(9): 1617-24. PMid:29869723. https://doi.org/10.1007/s00467-018-3966-7

[76] Dashti M, Scott JA, Edwards CA, et al. Predictors of breastfeeding duration among women in Kuwait: results of a prospective cohort study. Nutrients. 2014; 6(2): 711-28. PMid:24561360. https : //doi.org/10.3390/nu6020711

[77] AlSeaidan M, Al Wotayan R, Christophi CA, et al. Birth Outcomes in a Prospective Pregnancy-Birth Cohort Study of Environmental Risk Factors in Kuwait: The TRACER Study. Paediatric and Perinatal Epidemiology. 2016; 30(4): 408-17. PMid:27193754. https://doi.org/10.1111/ppe.12296

[78] Sadoun E, Leventakou V, Casas M, et al. A birth cohort study in the Middle East: the Qatari birth cohort study (QBiC) phase I. BMC public health. 2017; 17(1): 836. PMid:29061134. https: //doi.org/10.1186/s12889-017-4848-9

[79] al-Mazroui MJ, Oyejide CO, Bener A, et al. Breastfeeding and supplemental feeding for neonates in Al-Ain, United Arab Emirates. Journal of Tropical Pediatrics. 1997; 43(5): 304-6. PMid:9364130. https://doi.org/10.1093/tropej/43.5.304

[80] Gardner H, Green K, Gardner A. Infant Feeding Practices of Emirati Women in the Rapidly Developing City of Abu Dhabi, United Arab Emirates. International Journal of Environmental Research and Public Health. 2015;12(9):10923-40. PMid:26404348. https : //doi.org/10.3390/ijerph120910923

[81] Gardner H, Green K, Gardner AS, et al. Observations on the health of infants at a time of rapid societal change: a longitudinal study from birth to fifteen months in Abu Dhabi. BMC Pediatrics. 2018; 18(1): 32. PMid:29415674. https://doi.org/10.1186/s12887 $-018-1016-z$

[82] Naja F, Nasreddine L, Al Thani AA, et al. Study protocol: Mother and Infant Nutritional Assessment (MINA) cohort study in Qatar and Lebanon. BMC Pregnancy and Childbirth. 2016; 16: 98. PMid:27146913. https://doi.org/10.1186/s12884-016 $-0864-5$

[83] Kheirabadi GR, Maracy MR. Perinatal depression in a cohort study on Iranian women. Journal of research in medical sciences: the official journal of Isfahan University of Medical Sciences. 2010; 15(1): 41-9.

[84] Rajabi A, Maharlouei N, Rezaianzadeh A, et al. Non-medical factors affecting antenatal preferences for delivery route and actual delivery mode of women in southwestern Iran. The journal of maternal-fetal \& neonatal medicine : the official journal of the European Association of Perinatal Medicine, the Federation of Asia and Oceania Perinatal Societies, the International Society of Perinatal Obstet. 2016; 29(22): 3622-8. PMid:26753876. https://doi.org/10.3109/14767058.2016.1140137

[85] Abdollahi F, Zarghami M, Sazlina SG, et al. Stability of depressive symptoms over 3 months post-partum. Early intervention in Psychiatry. 2017; 11(1): 57-62. PMid:25582677. https://doi .org/10.1 111/eip. 12215

[86] Sharifzadeh F, Kashanian M, Jouhari S, et al. Relationship between pre-pregnancy maternal BMI with spontaneous preterm delivery and birth weight. Journal of obstetrics and gynaecology : the journal of the Institute of Obstetrics and Gynaecology. 2015; 35(4): 354 7. PMid:25383975. https : //doi.org/10.3109/01443615.201 4.968101

[87] Saki F, Dabbaghmanesh MH, Ghaemi SZ, et al. Thyroid autoimmunity in pregnancy and its influences on maternal and fetal outcome in Iran (a prospective study). Endocrine Research. 2015; 40(3): 139-45. PMid:25330412. https://doi.org/10.3109/07435800.2014. 966384

Published by Sciedu Press 
[88] Radfar M, Hashemieh M, Shirvani F, et al. Transcutaneous Bilirubinometry in Preterm and Term Newborn Infants before and during Phototherapy. Archives of Iranian Medicine. 2016; 19(5): 323-8.

[89] Kashi Z, Bahar A, Akha O, et al. Levothyroxine Dosage Requirement During Pregnancy in Well-Controlled Hypothyroid Women: A Longitudinal Study. Global Journal of Health Science. 2015; 8(4): 227-33. PMid:26573046. https ://doi.org/10.5539/gjhs .v8n4p227

[90] Gandevani SB, Banaem LM, Mohamadi B, et al. Association of high-sensitivity $\mathrm{C}$-reactive protein serum levels in early pregnancy with the severity of preeclampsia and fetal birth weight. Journal of perinatal medicine. 2012; 0(0): 1-5.

[91] Dolatian M, Mirabzadeh A, Forouzan AS, et al. Relationship between Structural and Intermediary Determinants of Health and Preterm Delivery. Journal of reproduction \& infertility. 2014; 15(2): 78-86.

[92] Afjeh SA, Sabzehei MK, Karimi A,et al. Surveillance of ventilatorassociated pneumonia in a neonatal intensive care unit: characteristics, risk factors, and outcome. Archives of Iranian Medicine. 2012; 15(9): 567-71.

[93] Amini E, Sheikh M, Hantoushzadeh S, et al. Maternal hyperuricemia in normotensive singleton pregnancy, a prenatal finding with continuous perinatal and postnatal effects, a prospective cohort study. BMC Pregnancy and Childbirth. 2014; 14: 104. PMid:24636149. https://doi.org/10.1186/1471-2393-14-104

[94] Borna S, Borna H, Khazardoost S, et al. 'Perinatal outcome in preterm premature rupture of membranes with Amniotic fluid index < 5 (AFI $<5)$. BMC pregnancy and childbirth. 2004; 4(1): 15. PMid:15291965. https://doi.org/10.1186/1471-2393-4-15

[95] Dadkhah F, Kashanian M, Bonyad Z, et al. Predicting neonatal weight of more than $4000 \mathrm{~g}$ using fetal abdominal circumference measure ment by ultrasound at 38-40 weeks of pregnancy: a study in Iran. The Journal of Obstetrics and Gynaecology Research. 2013; 39(1): 170-4. PMid:22690747. https://doi.org/10.1111/j.1447-0 756.2012.01918.x

[96] Dadkhah F, Kashanian M, Eliasi G. A comparison between the pregnancy outcome in women both with or without threatened abortion. Early Human Development. 2010; 86(3): 193-6. PMid:20231080. https://doi.org/10.1016/j.earlhumdev.2010.02.005

[97] Kalantari M, Negahdari A, Roknsharifi S, et al. A new formula for estimating fetal weight: The impression of biparietal diameter, abdominal circumference, mid-thigh soft tissue thickness and femoral length on birth weight. Iranian Journal of Reproductive Medicine. 2013; 11(11): 933-8.

[98] Kashanian M, Akbarian AR, Baradaran H, et al. Pregnancy outcome following a previous spontaneous abortion (miscarriage). Gynecologic and Obstetric Investigation. 2006; 61(3): 167-70. PMid:16428886. https ://doi.org/10.1159/000091074

[99] Keshavarz M, Cheung NW, Babaee GR, et al. Gestational diabetes in Iran: incidence, risk factors and pregnancy outcomes. Diabetes research and clinical practice. 2005; 69(3): 279-86. PMid:16098925. https://doi.org/10.1016/j.diabres.2005.01.011

[100] Khamoushi AJ, Kashfi F, Hosseini S, et al. Anti-coagulation during pregnancy in women with mechanical heart valves: a prospective study. International Journal of Fertility \& Sterility. 2011; 5(1): 47-51.

[101] Moini A, Shiva M, Arabipoor A, et al. Obstetric and neonatal outcomes of twin pregnancies conceived by assisted reproductive technology compared with twin pregnancies conceived spontaneously: a prospective follow-up study. European Journal of Obstetrics, Gynecology, and Reproductive Biology. 2012; 165(1): 29-32. PMid:22884795. https://doi.org/10.1016/j.ejogrb. 2012. 07.008

[102] Niromanesh S, Shirazi M, Dastgerdy E, et al. Association of hypertriglyceridaemia with pre-eclampsia, preterm birth, gestational diabetes and uterine artery pulsatility index. The National Medical Journal of India. 2012; 25(5): 265-7.

[103] Tavassoli F, Ghasemi M, Mohamadzade A, et al. Survey of pregnancy outcome in preterm premature rupture of membranes with amniotic fluid index $<5$ and $>/=5$. Oman Medical Journal. 2010; 25(2): 118-23. PMid:22125713. https ://doi.org/10.5001/omj . 2010.32

[104] Mirabzadeh A, Dolatian M, Forouzan AS, et al. Path analysis associations between perceived social support, stressful life events and other psychosocial risk factors during pregnancy and preterm delivery. Iranian Red Crescent Medical Journal. 2013; 15(6): 507-14. PMid:24349750. https://doi.org/10.5812/ircmj.11271

[105] Maghsoudlou S, Cnattingius S, Montgomery S, et al. Opium use during pregnancy and risk of preterm delivery: A population-based cohort study. PloS one. 2017; 12(4): e0176588. PMid:28448546. https ://doi.org/10.1371/journal.pone.0176588

[106] Ramezanali F, Arabipoor A, Hafezi M, et al. Serum estradiol level on trigger day impacts clinical pregnancy rate in modified natural frozen embryo transfer cycles. International journal of gynaecology and obstetrics: the official organ of the International Federation of Gynaecology and Obstetrics. 2019; 145(3): 312-8. PMid:30916782. https://doi.org/10.1002/ijgo.12806

[107] Kouhkan A, Khamseh ME, Pirjani R, et al. Obstetric and perinatal outcomes of singleton pregnancies conceived via assisted reproductive technology complicated by gestational diabetes mellitus: a prospective cohort study. BMC Pregnancy and Childbirth. 2018; 18(1): 495. PMid:30547777. https://doi.org/10.1186/s128 84-018-2115-4

[108] Rahimi V, Mohammadkhani G, Javadi F. Improving universal newborn hearing screening outcomes by conducting it with thyroid screening. International Journal of Pediatric Otorhinolaryngology. 2018; 111: 111-4. PMid:29958592. https://doi.org/10.1016/j.ij porl.2018.06.002

[109] Ghandi Y, Habibi D, Nasri K, et al. Effect of well-controlled gestational diabetes on left ventricular diastolic dysfunction in neonates. The journal of maternal-fetal \& neonatal medicine: the official journal of the European Association of Perinatal Medicine, the Federation of Asia and Oceania Perinatal Societies, the International Society of Perinatal Obstet. 2019; 32(13): 2101-6. PMid:29911451. https://doi.org/10.1080/14767058.2018.1425832

[110] Pirjani R, Afrakhteh M, Sepidarkish M, et al. 'Elective caesarean section at 38-39 weeks gestation compared to $>39$ weeks on neonatal outcomes: a prospective cohort study. BMC Pregnancy and Childbirth. 2018; 18(1): 140. PMid:29739452. https ://doi.org/10.1 $186 /$ s $12884-018-1785-2$

[111] Hashemipour S, Haji Seidjavadi E, Maleki F, et al. Level of maternal triglycerides is a predictor of fetal macrosomia in non-obese pregnant women with gestational diabetes mellitus. Pediatrics and Neonatology. 2018; 59(6): 567-72. PMid:29398554. https://doi.org/10 $.1016 / \mathrm{j} \cdot$ pedneo 2018.01 .008

[112] Kolahi AA, Abbasi-Kangevari M, Abdollahi M, et al. Pattern of prenatal care utilization in Tehran: A population based longitudinal study. Women and birth : Journal of the Australian College of Midwives. 2018; 31(3): e147-e51. PMid:28966128. https : //doi.org/10.1016/j.wombi.2017.09.013

[113] Naseh A, Ashrafzadeh S, Rassi S. Prevalence of vitamin D deficiency in pregnant mothers in Tehran and investigating its association with serum glucose and insulin. The journal of maternal-fetal \& neonatal medicine : the official journal of the European Association of Perinatal Medicine, the Federation of Asia and Oceania Perinatal Societies, the International Society of Perinatal Obstet. 2018; 31(17): 2312-8. PMid:28662591. https://doi .org/10.1080/14767058 .2017 .1342796 
[114] Zarshenas M, Zhao Y, Poorarian S, et al. Incidence and Risk Factors of Mastitis in Shiraz, Iran: Results of a Cohort Study. Breastfeeding medicine : the official journal of the Academy of Breastfeeding Medicine. 2017; 12: 290-6. PMid:28418698. https://doi.org/ $10.1089 / \mathrm{bfm} .2016 .0153$

[115] Maghbooli Z, Hossein-Nezhad A, Ramezani M, et al. Epigenetic Alterations and Exposure to Air Pollutants: Protocol for a Birth Cohort Study to Evaluate the Association Between Adverse Birth Outcomes and Global DNA Methylation. JMIR Res Protoc. 2017; 6(2): e29. PMid:28232302. https://doi.org/10.2196/resprot.7114

[116] Berkovitz A, Hershko-Klement A, Fejgin M. Nulliparity, fertility treatments and twins: a time for rethinking. Fertility and Sterility. 2010; 93(6): 1957-60. PMid:19249760. https://doi.org/10.1 016/j.fertnstert.2008.12.035

[117] Yohay D, Weintraub AY, Mauer-Perry N, et al. Prevalence and trends of pelvic floor disorders in late pregnancy and after delivery in a cohort of Israeli women using the PFDI-20. European Journal of Obstetrics, Gynecology, and Reproductive Biology. 2016; 200: 359. PMid:26967344. https://doi.org/10.1016/j.ejogrb. 201 6.02 .037

[118] Gottfried R, Lev-Wiesel R, Hallak M, et al. Inter-relationships between sexual abuse, female sexual function and childbirth. Midwifery. 2015; 31(11): 1087-95. PMid:26324214. https://doi.org/10.1 016/j.midw . 2015.07.011

[119] Shopen N, Schiff E, Koren-Morag N, et al. Factors That Predict the Development of Hypertension in Women With Pregnancy-Induced Hypertension. American Journal of Hypertension. 2016; 29(1): 141-6. PMid:26015330. https://doi.org/10.1093/ajh/hpv073

[120] Halperin O, Sarid O, Cwikel J. The influence of childbirth experiences on womens postpartum traumatic stress symptoms: A comparison between Israeli Jewish and Arab women. Midwifery. 2015; 31(6): 625-32. PMid:25840622. https://doi.org/10.1016/j. midw. 2015.02.011

[121] Lande Y, Seidman DS, Maman E, et al. Why do couples discontinue unlimited free IVF treatments? Gynecological endocrinology $:$ the official journal of the International Society of Gynecological Endocrinology. 2015; 31(3): 233-6. PMid:25414079. https: //doi.org/10.3109/09513590.2014.982082

[122] Kaitz M, Mankuta D, Rokem AM, et al. Moderate antenatal anxiety symptoms and birth outcomes of boys and girls. Journal of Psychosomatic Obstetrics and Gynaecology. 2014; 35(4): 116-23. PMid:25204367. https://doi.org/10.3109/0167482X . 2014. 952279

[123] Eldar-Geva T, Srebnik N, Altarescu G, et al. Neonatal outcome after preimplantation genetic diagnosis. Fertility and Sterility. 2014. PMid:25064409. https://doi.org/10.1016/j.fertnstert.2 014.06 .023

[124] Juster-Reicher A, Flidel-Rimon O, Rozin I, et al. Correlation of transcutaneous bilirubinometry $(\mathrm{TcB})$ and total serum bilirubin (TsB) levels after phototherapy. The journal of maternal-fetal \& neonatal medicine: the official journal of the European Association of Perinatal Medicine, the Federation of Asia and Oceania Perinatal Societies, the International Society of Perinatal Obstet. 2014: 1-3. PMid:25234102. https://doi .org/10.3109/14767058.2014. 953923

[125] Salim R, Hasanein J, Nachum Z, et al. Anthropometric parameters in infants of gestational diabetic women with strict glycemic control. Obstetrics and Gynecology. 2004; 104(5 Pt 1): 1021-4. PMid:15516395. https://doi.org/10.1097/01.AOG.0000143 821.00194.ad

[126] Shinwell ES, Blickstein I, Lusky A, et al. Excess risk of mortality in very low birthweight triplets: a national, population based study.
Archives of Disease in Childhood Fetal and Neonatal Edition. 2003; 88(1): F36-40. PMid:12496224. https://doi.org/10.1136/fn .88.1.F36

[127] Weisz B, Hogen L, Yinon Y, et al. Perinatal outcome of monochorionic twins with selective IUGR compared with uncomplicated monochorionic twins. Twin research and human genetics : the official journal of the International Society for Twin Studies. 2011; 14(5): 457-62. PMid:21962139. https://doi.org/10.1375/twin.14.5.457

[128] Mor A, Tal R, Irani M, et al. Carcinoembryonic antigen as a biomarker for meconium-stained amniotic fluid. International journal of gynaecology and obstetrics: the official organ of the International Federation of Gynaecology and Obstetrics. 2016; 132(3): 329-31. PMid:26674317. https://doi.org/10.1016/j.ijgo.2015.07 .032

[129] Haas J, Hourvitz A, Dor J, et al. Pregnancy outcome of early multifetal pregnancy reduction: triplets to twins versus triplets to singletons. Reproductive biomedicine online. 2014; 29(6): 717-21. PMid:25444505. https://doi.org/10.1016/j.rbmo.2014.09 .003

[130] Ravid E, Salzer L, Arnon L, et al. Is there an association between maternal anxiety propensity and pregnancy outcomes? BMC Pregnancy and Childbirth. 2018; 18(1): 287. PMid:29973180. https: //doi.org/10.1186/s12884-018-1925-8

[131] Weinstein Y, Levav I, Gelkopf M, et al. Association of maternal exposure to terror attacks during pregnancy and the risk of schizophrenia in the offspring: A population-based study. Schizophrenia Research. 2018; 199: 163-7. PMid:29685420. https://doi.org/10.1016/ j.schres.2018.04.024

[132] Shitrit AB, Cohen Y, Hassin O, et al. Antenatal Management for Women with Inflammatory Bowel Disease: Experience from Our 'IBD MOM' Clinic. Digestive diseases and sciences. 2018; 63(7): 1774-81. PMid:29626275. https://doi.org/10.1007/s10620 $-018-5048-x$

[133] Samuel TY, Bromiker R, Mimouni FB, et al. Newborn oxygen saturation at mild altitude versus sea level: implications for neonatal screening for critical congenital heart disease. Acta Paediatrica. 2013; 102(4): 379-84. PMid:23298328. https ://doi .org/10.1111/ap a. 12155

[134] Awwad J, Usta IM, Succar J, et al. The effect of maternal fasting during Ramadan on preterm delivery: a prospective cohort study. BJOG : an International Journal of Obstetrics and Gynaecology. 2012; 119(11): 1379-86. PMid:22827751. https ://doi.org/10 $.1111 / \mathrm{j} .1471-0528.2012 .03438 . \mathrm{x}$

[135] Abdulsalam AA, Bashour HN, Monem FS, et al. Pregnancy outcomes among Palestinian refugee women with sickle cell trait in Damascus, Syria. Saudi Medical Journal. 2003; 24(9): 986-90.

[136] Batieha AM, Khader YS, Berdzuli N, et al. Level, Causes and Risk Factors of Neonatal Mortality, in Jordan: Results of a National Prospective Study. Maternal and Child Health Journal. 2016; 20(5): 1061-71. PMid:26645614. https://doi.org/10.1007/s10995 $-015-1892-x$

[137] Kassab M, Shaban I, Mohammad K, et al. Prevalence of Hypovitaminosis D Among Jordanian Healthy Infants: A Descriptive Cross Sectional Study. Journal of Pediatric Nursing. 2016; 31(2): e119-25. PMid:26577996. https://doi.org/10.1016/j . pedn.2015.10 .004

[138] Al-Essa M, Azad RV, Rashwan N. Threshold stage of retinopathy of prematurity: maternal and neonatal risk factors. Annals of Saudi Medicine. 2000; 20(2): 129-31. PMid:17322709. https: //doi.org/10.5144/0256-4947.2000.129

[139] Abdel AA, Abd RA, Sayed AWA, et al. Validation of the closeto-delivery prediction model for vaginal birth after cesarean de- 
livery in a Middle Eastern cohort. International Journal of Gynaecology and Obstetrics. 2016; 134(1): 75-8. PMid:27118509. https://doi.org/10.1016/j.ijgo.2015.11.021

[140] Gowri V, Mathew M, Gravell D, et al. Protein Z levels in pregnant Omani women: correlation with pregnancy outcome. Journal of Thrombosis. 2011; 32(4): 453-8. PMid:21837382. https : //doi.org/10.1007/s11239-011-0629-y

[141] Villar J, Altman DG, Purwar M, et al. The objectives, design and implementation of the INTERGROWTH-21st Project. BJOG. 2013;120 Suppl 2: 9-26, v. PMid:23678873. https://doi.org/10.1111/ 1471-0528.12047

[142] Aguilar Cordero MJ, Batran Ahmed SM, Padilla Lopez CA, et al Breast feeding in premature babies: development-centered care in Palestine. Nutricion Hospitalaria. 2012; 27(6): 1940-4.

[143] Qandil S, Jabr S, Wagler S, et al. Postpartum depression in the Occupied Palestinian Territory: a longitudinal study in Bethlehem BMC Pregnancy and Childbirth. 2016; 16(1): 375. PMid:27887649. https ://doi.org/10.1186/s12884-016-1155-x

[144] Hassan SJ, Wick L, DeJong J. A glance into the hidden burden of maternal morbidity and patterns of management in a Palestinian governmental referral hospital. Women and birth : journal of the Australian College of Midwives. 2015; 28(4): e148-56. PMid:25049697. https://doi.org/10.5713/ajas.2012.12023

[145] Zimmo M, Laine K, Hassan S, et al. Differences in rates and odds for emergency caesarean section in six Palestinian hospitals: a population-based birth cohort study. BMJ Open. 2018; 8(3): e019509. PMid:29500211. https://doi.org/10.1136/bmjope n-2017-019509

[146] El-Gilany AH, Hammad S. Body mass index and obstetric outcomes in pregnant in Saudi Arabia: a prospective cohort study. Annals of Saudi Medicine. 2010; 30(5): 376-80. PMid:20697173. https://doi.org/10.4103/0256-4947.67075

[147] Kensara OA, Azzeh FS. Nutritional status of low birth weight infants in Makkah region: Evaluation of anthropometric and biochemical parameters. JPMA. 2016; 66(4): 414-7.

[148] El-Kersh TA, Marie MA, Al-Sheikh YA, et al. Prevalence and risk factors of early fecal carriage of Enterococcus faecalis and Staphylococcus spp and their antimicrobial resistant patterns among healthy neonates born in a hospital setting in central Saudi Arabia. Saudi Medical Journal. 2016; 37(3): 280-7. PMid:26905350. https://doi .org/10.15537/smj . 2016.3.13871

[149] Sallout B, Obedat N, Shakeel F, et al. Prevalence of major congenital anomalies at King Fahad Medical City in Saudi Arabia: a tertiary care centre-based study. Annals of Saudi Medicine. 2015; 35(5): 343-51. PMid:26506967. https ://doi.org/10.5144/0256-4947.2015 .343

[150] Shirah BH, Shirah HA, Fallata AH, et al. Hemorrhoids during pregnancy: Sitz bath vs. ano-rectal cream: A comparative prospective study of two conservative treatment protocols. Women and birth : Journal of the Australian College of Midwives. 2018; 31(4): e272-e7. PMid:29055673. https://doi.org/10.1016/j. wombi.2017.1 0.003

[151] Sedaghatian MR, Othman L, Hossain MM, et al. Risk of meconiumstained amniotic fluid in different ethnic groups. Journal of perinatology : official journal of the California Perinatal Association. 2000; 20(4): 257-61. PMid:10879341. https://doi.org/10.1038/sj .jp. 7200367

[152] Hammoud MS, Al-Taiar A, Al-Abdi SY, et al. Culture-proven earlyonset neonatal sepsis in Arab states in the Gulf region: two-year prospective study. IJID. 2017; 55: 11-5. PMid:27979783. https: //doi.org/10.1016/j.ijid.2016.12.006

[153] Christian SJ, Boama V, Satti H, et al. Metformin or insulin: logical treatment in women with gestational diabetes in the Middle East, our experience. BMC. 2018; 11(1): 426. PMid:29970197. https://doi.org/10.1186/s13104-018-3540-1

[154] Ibrahim WH, Rasul F, Ahmad M, et al. Asthma knowledge, care, and outcome during pregnancy: The QAKCOP study. Chronic Respiratory Disease. 2019; 16: 147. PMid:29621888. https://doi.org/ 10.1177/1479972318767719

[155] Al-Shahethi AH, Zaki RA, Al-Serouri AWA, et al. Maternal, prenatal and traditional practice factors associated with perinatal mortality in Yemen. Women and birth: Journal of the Australian College of Midwives. 2019; 32(2): e204-e15. PMid:30030021. https : //doi.org/10.1016/j.wombi.2018.06.016

[156] Obadi MA, Taher R, Qayad YS. Risk fac M, Khader tors of stillbirth in Yemen. Journal of Neonatal-perinatal Medicine. 2018; 11(2): 1316. PMid:29843265. https://doi .org/10.3233/NPM-181746 